\title{
Turnkey Contract - A Management Challenge under Himalayan Geological Condition
}

\section{Dr. Krishna Kanta Panthi}

Abstract: Himalayan geology poses special attention and tunnelling challenges, which are associated to the engineering geological conditions in the rock mass. Completing tunnelling project within scheduled contractual time is an issue to be carefully brainstormed and planned by a very competent project management team. This team work is especially a key demand for the projects built under turnkey contract having fixed performance guarantees, completion milestones and contract sum. This is because, delay in construction completion will bring huge contractual penalties and extra cost to the contractor and is, therefore, a management headache to the project team. Hydropower projects consisting long underground waterways system passing through varying geological ground conditions may hinder achieving targeted milestones due to uncertainty associated to the geological risks.

This paper present Khimti I Hydropower Project (60 MW) that has $10 \mathrm{~km}$ long underground waterway system, one km long access tunnel, many construction Adits and an underground powerhouse. The project was constructed under a turnkey contract called KC2 contracts with main civil contractor responsible for both design and construction implementation of the project. The construction quality was guaranteed through several contractual performance tests listed under the KC2 contract. This article attempts to review on the way the geological ground condition has influenced in the completion milestone of the project and highlights on what are the key issues that must be carefully accessed before accepting a turnkey contract for hydropower project with long underground waterway systems.

Keywords: Khimti I Hydropower Project, Turnkey, Tunnelling, Nepal

\section{Background}

The rock mass quality along the tunnel alignment 1 varies greatly over the length and this is associated to the intensity of fracturing, weathering, hydrogeology and tectonic history of the area of concern. Knowing rock mass quality prior to the construction of the project is a serious challenge and a careful preconstruction phase investigation is important. It is highlighted here that the ability to better comprehend the rock mass conditions along the tunnel alignment increases as project development stage moves on as shown in Figure 1 below.

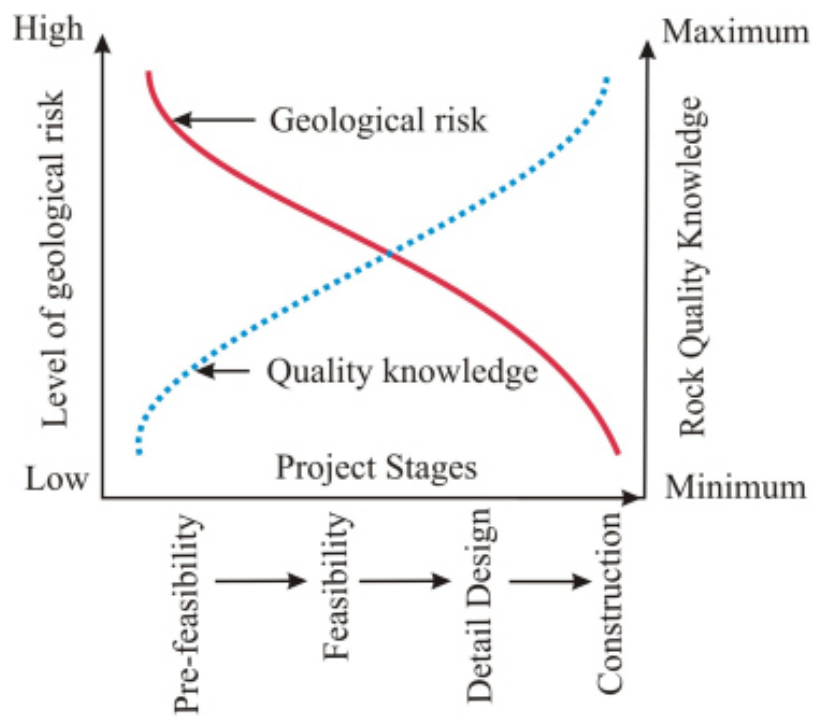

Figure 1: Illustration of geological risk versus rock quality knowledge over development stage.

This change in quality knowledge is associated to the extent of engineering geological investigations, site explorations and in-situ as well as laboratory testing activities, which increase steadily over the planning and construction of the tunnelling projects. As Figure 1 explains, the actual rock mass condition of an underground structure is fully known only after the completion of its excavation work (Panthi, 2006). On the other hand, basic design and economic viability evaluation of a hydropower project consisting many underground elements such as headrace tunnel, shaft, tailrace and access tunnel and underground powerhouse and transformer caverns has to be made during its feasibility study stage. On the basis of technical and economic feasibility further recommendations are made for the implementation (Panthi and Nilsen, 2007).

Regarding Himalayan geology, the degree of geological risks for underground elements of a hydropower project are higher in the Himalayan region due to both geological complexity, not fully known knowledge of the area beforehand and inadequate pre-construction phase investigations on geological conditions. The tunnelling experience shows that almost all projects in general suffer considerable financial setback while implementing hydropower projects in this region. The geological variations on predicted and actual ground rock mass conditions leads to the considerable deviation on estimated project construction cost, delayed construction completion and contractual disputes. The turnkey contracts are special contracts and it is crucial to have well planned strategies to address the challenge associated to the geological risks to achieve cost effectiveness and timely completion of the project. Failing to achieve this will lead to excessive financial loss caused by not only due to the existence of strong penalties (liquidated damage) provisions kept in the construction contract but also due to increased construction costs caused by the variation in the rock mass (geological) conditions. 
This paper aims to review the turnkey civil work contract (KC2 contract) of the Khimti I Hydropower Project (6o MW), which construction was completed in 2001. The project experienced considerable variation in the rock mass condition along the waterway system than what was anticipated during signing of the civil work contract. The KC2 Turnkey Contract gave sole responsibility in carrying out design and construction of all civil works based on the quality control document called "Design Basin Memorandum" (HPL, 1996a). The paper also briefly highlights on the contractor's management structure, main elements of the contract and variation experienced in the geological conditions of various underground works.

\section{The Project}

The Khimti I Hydropower Project diverts water from the Khimti River, which is also a boundary River separating Dolakha district with Ramechhap. Most of the project structures and construction activities except Headworks (dam site) are in Dolakha district. This development of Hydropower Project through private investment after the privatization policy that the Government of Nepal (GoN) initiated in 1992 after the promulgation of the "Electricity Act of Nepal". This Act set-down the principles for granting licences to private parties to undertake hydropower projects development in Nepal, which is becoming more and more popular in recent years.

In January 1996, the Government of Nepal awarded licence to Himal Power Limited (HPL) for the construction and operation of Khimti I Hydropower Project under BOOT (Built, Own, Operate and Transfer) concept. HPL received commercial loan from the lenders group comprising Asian Development Bank (ADB), International Monitory Fund (IMF), Nordic Development Fund (NDF) and NORAD of Norway. The lender group also assigned its Independent Engineer with the responsibility to review all aspects of design, contractual relations and environmental impact of the project. The run-of-river (RoR) Khimti I Hydropower Project with a layout plan shown in Figure 2 has an installed capacity of $60 \mathrm{MW}$ with an annual generation capacity amounting to 350 GWh (HPL, 1996b and CCC, 2002). Project represents a milestone in Nepal regarding the

The main salient features of the Khimti I Hydropower Project is given in Table 1, which has typical features such as high head, relatively small cross-section (14 sq. m.) of the waterway tunnel system, two 45 degrees inclined penstock shafts of one kilometre length, five medium units (12 MW each) Pelton turbines, limited environmental impacts, limited impact on the land users and existing communities, favourable Power Purchase Agreement (PPA) with Nepal Electricity Authority (NEA), the Government owned electricity utility authority in Nepal.

\begin{tabular}{|l|c|c|l|c|c|}
\hline $\begin{array}{l}\text { Descrip- } \\
\text { tions }\end{array}$ & Unit & $\begin{array}{l}\text { Quantity/ } \\
\text { Amount }\end{array}$ & $\begin{array}{l}\text { Descrip- } \\
\text { tions }\end{array}$ & Unit & $\begin{array}{l}\text { Quan- } \\
\text { tity/ } \\
\text { Amount }\end{array}$ \\
\hline $\begin{array}{l}\text { Design } \\
\text { Dis- } \\
\text { charge }\end{array}$ & $\mathrm{m}^{3} / \mathrm{s}$ & 10.75 & $\begin{array}{l}\text { Construc- } \\
\text { tion adits } \\
\text { length }\end{array}$ & $\mathrm{m}$ & 1052 \\
\hline $\begin{array}{l}\text { Gross } \\
\text { head }\end{array}$ & $\mathrm{m}$ & 684 & $\begin{array}{l}\text { Under- } \\
\text { ground } \\
\text { power- } \\
\text { house }\end{array}$ & - & $\begin{array}{c}12 \mathrm{~m} \mathrm{~m} \\
60 \mathrm{~m}\end{array}$ \\
\hline $\begin{array}{l}\text { Net head } \\
\text { Water } \\
\text { way } \\
\text { length }\end{array}$ & $\mathrm{m}$ & 660 & $\begin{array}{l}\text { Excavation } \\
\text { volume at } \\
\text { dam site }\end{array}$ & $\mathrm{m}^{3}$ & 120000 \\
\hline m & 10000 & $\begin{array}{l}\text { Concrete } \\
\text { work at } \\
\text { dam site }\end{array}$ & $\mathrm{m}^{3}$ & 18000 \\
\hline tunnel & $\mathrm{m}$ & 890 & $\begin{array}{l}\text { Bolder rip- } \\
\text { rap work } \\
\text { including } \\
\text { gabions } \\
\text { for slope } \\
\text { stabiliza- } \\
\text { tion }\end{array}$ & $\mathrm{m}^{3}$ & 19500 \\
\hline
\end{tabular}

Table 1: Main salient features of the Khimti I Hydropower Project (CCC, 2002)

The project had also features such as fixed construction period (48 months), Technology Transfer Program (TTP) to build local capabilities in design, construction and contract management and employment opportunity to the local population in the districts (CCC, 2002).

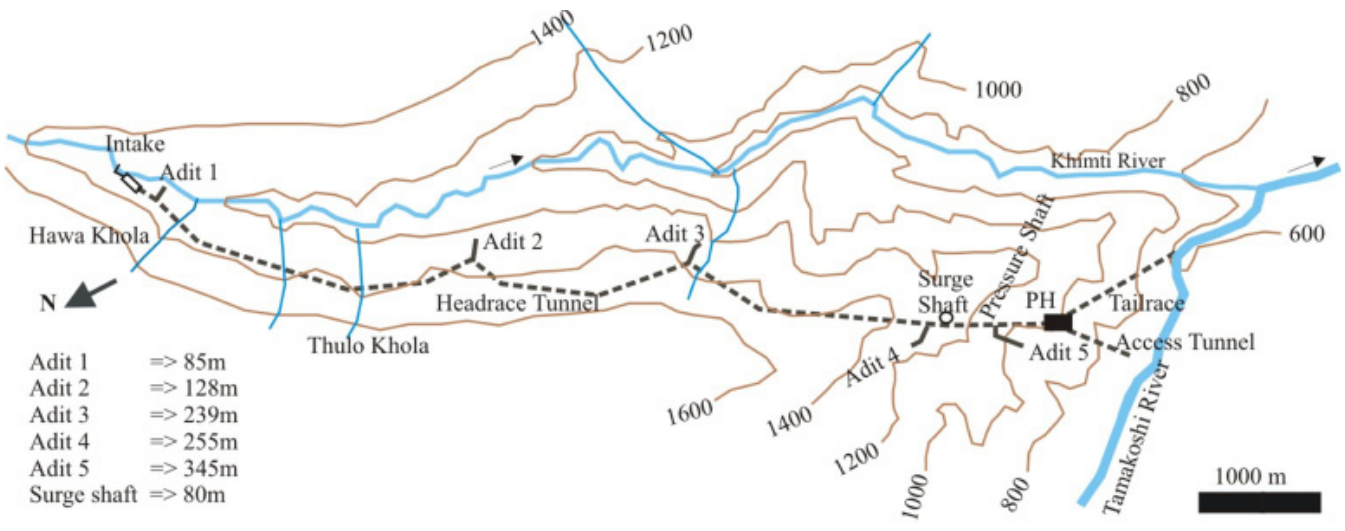

The Civil Work Contract

There were three main contracts that the owner of the project, HPL, signed with different parties to implement the Khimti I $\mathrm{H}$ y d r o p o w e r Project. These three main contracts were;

Figure 2: The layout arrangement of Khimti I Hydropower Project 
I. The $\mathrm{KC} 2$ - Civil Construction and Engineering Contract,

II. The ESIC - Equipment Supply and Installation Contract, and

III.The MC - Management Contract: a contract for construction supervision and quality Verification.

The KC2 contract was associated with the Civil Construction Consortium (CCC), a consortium comprising Statkraft Anlegg AS of Norway and Himal Hydro of Nepal. Whereas, the ESIC contract was associated with the consortium of Kværnar Energy of Norway and ABB International and the MC contract was associated with the consortium of Statkraft Engineering AS of Norway and BPC Hydroconsult of Nepal. The issues presented in this paper are related to Civil Construction and Engineering Contract, i.e. The KC2 Contract.

\section{The KC2 Contract}

The KC2 and the ESIC Contracts were Turnkey contracts very similar in style and were written as backto-back contracts. Overall format adopted in writing this Contract was almost similar to FIDIC 4th edition structure with the exception that the Engineer's power and authority with respect to making and ordering variations were largely removed and risk sharing between the owner, HPL and the contractor (CCC) were largely eliminated. Item such as geological risk were wholly passed over to the Civil Construction Consortium (CCC) - The Civil Contractor (CCC, 2002). CCC was also responsible in co-ordinating with ESIC for electro-mechanical design and installation works. The project was regulated based on several provisions of the Milestone achievement and the fixed date ready for Commercial Operation and payment was structured based on the completion milestones (Table 2).

\begin{tabular}{|c|l|c|c|c|}
\hline $\begin{array}{c}\text { MS } \\
\text { No. }\end{array}$ & $\begin{array}{l}\text { Description of } \\
\text { achievement }\end{array}$ & $\begin{array}{l}\text { Financial } \\
\text { Closure } \\
\text { + Days }\end{array}$ & $\begin{array}{l}\text { Contrac- } \\
\text { tual Date }\end{array}$ & $\begin{array}{c}\text { Approx. } \\
\text { Pay- } \\
\text { ment } \\
\text { (\%) }\end{array}$ \\
\hline 1 & $\begin{array}{l}\text { Financial Clo- } \\
\text { sure }\end{array}$ & - & $26-06-1996$ & 20 \\
\hline 2 & $\begin{array}{l}\text { Access Tunnel } \\
500 m \text { excava- } \\
\text { tion completion }\end{array}$ & 120 & $24-10-1996$ & 7 \\
\hline 3 & $\begin{array}{l}\text { Adit 4 tunnel } \\
180 m \text { excava- } \\
\text { tion completion }\end{array}$ & 213 & $25-01-1997$ & 6 \\
\hline 4 & $\begin{array}{l}\text { Lower Inclined } \\
\text { Shaft Alimak } \\
\text { installation }\end{array}$ & 304 & $26-04-1997$ & 8 \\
\hline 5 & $\begin{array}{l}275 \text { m exc. of } \\
\text { Headrace Tun- } \\
\text { nel upstream } \\
\text { Adit 4 }\end{array}$ & $\begin{array}{l}200 \text { m exc. of } \\
\text { Lower Inclined } \\
\text { Shaft }\end{array}$ & 486 & $25-10-1997$ \\
\hline
\end{tabular}

\begin{tabular}{|c|l|c|c|c|}
\hline 7 & $\begin{array}{l}925 \text { m exc. of } \\
\text { Headrace Tun- } \\
\text { nel upstream } \\
\text { Adit 4 }\end{array}$ & 577 & $24-01-1998$ & 7 \\
\hline 8 & $\begin{array}{l}440 \text { m exc. of } \\
\text { Lower Inclined } \\
\text { Shaft }\end{array}$ & 669 & $26-04-1998$ & 7 \\
\hline 9 & $\begin{array}{l}\text { Lower Inclined } \\
\text { Shaft ready for } \\
\text { penstock instal- } \\
\text { lation }\end{array}$ & 756 & $22-07-1998$ & 6 \\
\hline 10 & $\begin{array}{l}\text { Upper Inclined } \\
\text { Shaft ready for } \\
\text { penstock instal- } \\
\text { lation }\end{array}$ & 820 & $24-09-1998$ & 6 \\
\hline 11 & $\begin{array}{l}\text { Powerhouse } \\
\text { ready for elec- } \\
\text { tro-mechanical } \\
\text { installation }\end{array}$ & 968 & $19-02-1999$ & 12 \\
\hline 12 & $\begin{array}{l}\text { Waterway } \\
\text { ready for final } \\
\text { water filling }\end{array}$ & 1230 & $08-11-1999$ & 7 \\
\hline 13 & $\begin{array}{l}\text { Substantial } \\
\text { completion }\end{array}$ & 1354 & $11-03-2000$ & 0 \\
\hline 14 & $\begin{array}{l}\text { Commercial } \\
\text { operation of the } \\
\text { plant }\end{array}$ & 1467 & $11-07-2000$ \\
\hline & $\begin{array}{l}\text { Total } \\
\mathbf{7}\end{array}$ & $\mathbf{7 ~ D a y s}$ & 1 \\
\hline & & & 700 \\
\hline
\end{tabular}

Table 2: Different Milestones set in the KC2 Contract (HPL, 1996c)

\section{Special Features of KC2 Contract}

There were several provisions set in the $\mathrm{KC} 2$ Contract (HPL, 1996b) that restricted the Contractor for any further financial claims and provisions to make sure that the project was delivered in such a way that it functions as planned. Some of the most important with respect to financial implication to the Civil Contractor were highlighted below.

- Performance Security for the benefit of the Client amounting to US\$20 Million, which shall be held by the client until the issuance of the Tax Clearance Certificate or the expiry of the Defect Liability Period, whichever occurred the last.

- All data on hydrological and subsurface conditions that were made available by the client to the contractor were for information only and the Client did not hold any responsibility for the accuracy or adequacy and the Contractor had to bear all costs and expenses caused by any variation and also the Contractor was responsible for the costs and delays in completing the project including revenue loss by the Client due to delayed start of the electricity production from the plant.

- In the event that the Contractors (both Civil and 
Electro-mechanical) did not achieved Substantial Completion date indicated under MS 13 in Table 2, the Contractor had to pay to the Client an amount equal to US\$27,000 per day as liquidated damage until the Substantial Completion was achieved. The maximum amount of Liquidated damage was however fixed to its maximum up to US\$ 10.5 Million.

- Provision for the extension of time for completion in the event of additional civil works ordered by the Client, Force Majeure Event, Default by the Client, Delayed Performance Test due to insufficient flow in the River or incomplete

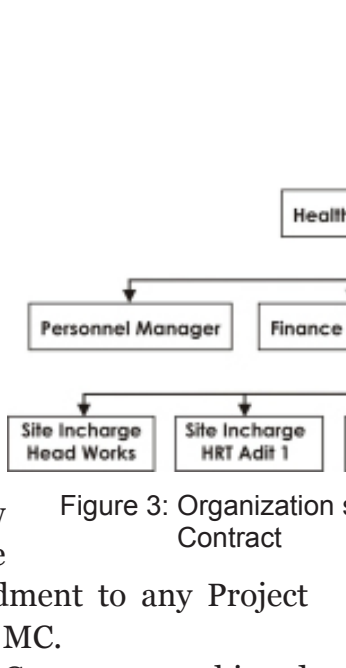
Contracts including ESIC and MC.

- In the event that the Contractors achieved Substantial Completion date before as indicated under MS 13 or in case the Contractors get time extension caused by issues explained above, the Contractors were entitled to be awarded with a bonus amounting US\$12,000 per day to KC2 Contractor and US\$ 8,00o to ESIC Contractor.

- Provision for several Guaranteed Performance Standard Tests (HPL, 1996c) with the provision of penalty consisting Specified Settling Basin Performance, Specified Leakage through the Dam and Intake Structures, Specified Leakage through the Waterway System, Specified Net Head of $660 \mathrm{~m}$ and Guaranteed Output of 60 MW.

\section{KC2 Contractor's Management Structure}

The Civil Construction Consortium (CCC), the civil contractor for design and execution of all civil works under $\mathrm{KC} 2$ Contract, was a consortium of Statkraft Anlegg AS, Norway and Himal Hydro, Nepal with a shear structure of 66 and 33 percentages, respectively. The relationship between the two consortium partners was governed by the Consortium Agreement (CCC, 2002). The key elements of the partnership were allocation of financial responsibility, formation of Executive Committee and Supervisory Board, formation of the project management team and payment structure to the members for their services. All the arrangement made for the construction of Khimti I Hydropower Project functioned well. The project suffered several changes in the top management for the first half period (until middle 1998) and as a result the project experienced set-backs in achieving the milestones set forth with an estimated delay in the Substantial Completion of project by approximately 150 days. With the substantial changes made in the top management by appointing new Project and Construction Managers, the situation has changed dramatically. After the middle of 1998 the CCC had an organization structure as presented in Figure 3 below.

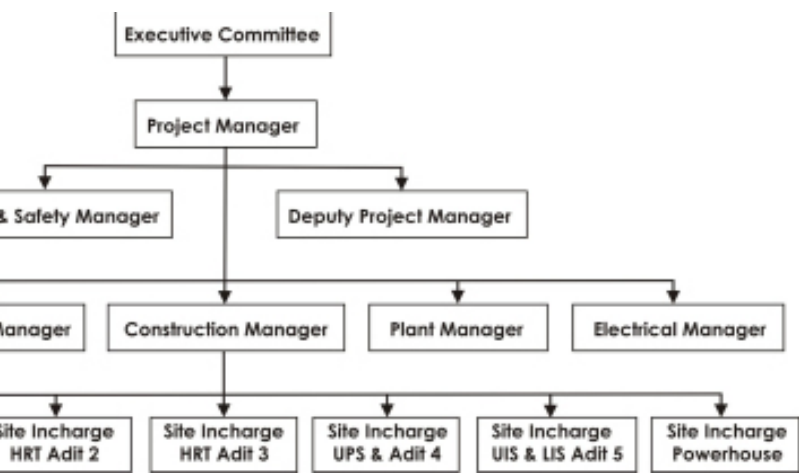

HRT Adit $20 \begin{gathered}\text { Site Inchar } \\ \text { HRT Adit }\end{gathered}$

With new Project and Construction Managers who had previous experience in managing construction works of similar type of hydropower project in Nepal gave possibility to improve the work activities from very grass-root level of the project. The team work was well established with very clear work responsibility from top to bottom, which helped to energize whole project team. The end results were exciting as well as rewarding, which resulted to achieve an early completion of the project.

\section{Review on Geological Risk}

The rock mass is a heterogeneous medium and therefore there exist many geological risk (challenges) associated to tunnelling works. More importantly, if the pre-construction phase investigations are not reliable, the extent of geological risk increases considerably. The geological risk, hence, mainly related to the combination of the facts like spatial variability of rock mass behaviour, tectonic history of the area of concern, level of pre-construction phase investigations and technique \& methods used for such investigations. The geological risk that the Civil Contractor had faced while implementing Khimti I Hydropower Project is briefly reviewed below.

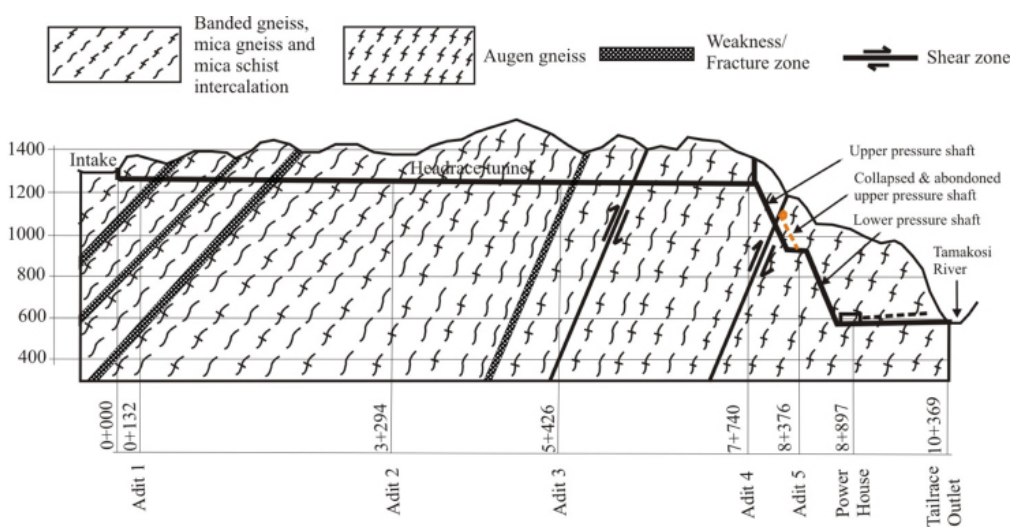

Figure 4: Geology along the waterway system of Khimti I Hydropower Project 


\section{Geology of the Project Area}

The Khimti I Hydropower Project is located in the crystalline Tamakoshi gneiss complex of the lesser Himalaya and the area is bounded by a major fault system of the Himalaya called "Main Central Thrust (MCT)". The rocks in the project area are mainly augen gneiss, banded gneiss and mica gneiss. The rock mass observed was schistose and influenced by the intercalation effect of bands of chlorite and talcose micaschist Figure 4.

The level of intercalation varies greatly over the length. The rock mass at the upstream segment of the headrace tunnel (up to Adit 2 junction) was banded gneiss that had wide interval between the sheared micaschist bands. The rock mass between Adit 2 and upper part of the upper pressure shaft where mica gneiss was the main dominating rock had micaschist band intercalation between 5 and 10 meters. The rock mass at the remaining inclined upper pressure shaft, 100 meter horizontal segment of pressure shaft, lower pressure shaft, powerhouse, tailrace and access tunnels, augen gneiss was the dominating rock where micaschist bands were met at wider interval. The foliation planes at the project area were generally striking towards northeast southwest direction and were dipping towards northwest. Since the project area is bounded with MCT, the rock mass in the project area were jointed. This jointing effect was more pronounced along headrace tunnel where highly sheared, deeply weathered and deformed rock mass were encountered. The area was also influenced by several minor faults and weakness zones represented by very weak and sheared micaschist and fractured zones (Panthi, 2013).

\section{Pre-construction phase investigation}

A summary of the preconstruction phase engineering geological investigations carried out at Khimti I Hydropower Project are presented in Table 3. As seen in the table, the level of investigations carried out along most of the headrace tunnel alignment was mainly limited to the desk study and surface mapping of the rock exposure, which were very limited and in many occasion not reachable. The refraction seismic was only done at the surge tank area and in addition $84 \mathrm{~m}$ long construction Adit was excavated at Adit 4 during design and contract preparation period. However, this construction Adit was abandoned later due to small size, which restricted mechanizing tunnelling.
Hence, the knowledge about rock mass conditions along the headrace tunnel was very limited and rock mass quality along headrace tunnel was one of the major risks that the Civil Contractor confronted during tunnel excavation.

\section{Rock Mass Quality along Headrace Tunnel}

The Design Basis Memorandum (HPL, 1996a), which was one of the most important part of the Turnkey contract and a main guideline for the Contractor to carry out detail design and construction work of Khimti I Hydropower Project. Regarding the quality of rock mass along the headrace tunnel the Design Basis Memorandum stated that "Most of the headrace tunnel will be in sound rocks with the exceptions on the construction Adits, the initial section close to intake and at the downstream end of the headrace tunnel at Adit 4 area where lining might be needed". This description on the rock mass quality was based on the rock mass that was met while excavating $84 \mathrm{~m}$ Adit 4 , the core drilling and refraction seismic carried out at surge shaft area and surface field mapping of the limited exposure (Table 3).

\begin{tabular}{|c|c|c|c|}
\hline Study Stage & Investigation Items & $\begin{array}{c}\text { State of } \\
\text { Investigation }\end{array}$ & Remarks \\
\hline \multirow{5}{*}{$\begin{array}{l}\text { Feasibility } \\
\text { Study }\end{array}$} & $\begin{array}{l}\text { Desk studies on the } \\
\text { existing geological } \\
\text { information and aerial } \\
\text { photo interpretations }\end{array}$ & Yes & $\begin{array}{l}\text { Geological map at scale of } \\
1: 125,000 \text { and Aerial photos at } \\
\text { scale } 1: 50,000 \text {. }\end{array}$ \\
\hline & $\begin{array}{l}\text { Surface geological } \\
\text { mapping }\end{array}$ & Yes & $\begin{array}{l}\text { Most of the area is covered } \\
\text { by vegetation and weathered } \\
\text { overburden material with few } \\
\text { rock mass exposure. }\end{array}$ \\
\hline & Refraction seismic & Yes & $\begin{array}{l}\text { Only at surge shaft area at } \\
\text { Adit } 4\end{array}$ \\
\hline & Electrical resistivity & No & \\
\hline & Laboratory testing & No & Only petrography \\
\hline \multirow{3}{*}{$\begin{array}{l}\text { Design, } \\
\text { contract } \\
\text { document } \\
\text { preparation } \\
\text { and award }\end{array}$} & $\begin{array}{l}\text { Review of the feasibility } \\
\text { study investigations }\end{array}$ & Yes & $\begin{array}{l}\text { More focus on the hydrol- } \\
\text { ogy but not on the geological } \\
\text { conditions. }\end{array}$ \\
\hline & $\begin{array}{l}\text { Detailed surface map- } \\
\text { ping }\end{array}$ & Yes & $\begin{array}{l}\text { Limited information due to } \\
\text { vegetation and weathering } \\
\text { excluding mapping inside } \\
\text { construction Adits. }\end{array}$ \\
\hline & $\begin{array}{l}\text { Construction Adit exca- } \\
\text { vation }\end{array}$ & Yes & $\begin{array}{l}84 \mathrm{~m} \text { at Adit } 4 \text { (abandoned } \\
\text { during construction) and } \\
190 \mathrm{~m} \text { Adit } 5 \text { and } 283 \mathrm{~m} \text { Access } \\
\text { Tunnel to } \mathrm{PH} \text {. }\end{array}$ \\
\hline
\end{tabular}

Table 3: Pre-construction phases engineering geological investigations

The Contractor was hopeful that rock mass along the headrace tunnel would be homogeneous and of good quality as were described in both Design Basis Memorandum (HPL, 1996a) and the Feasibility Study Report (MoWR, 1993). Even though, prediction made was one of the major geological risk to the Contractor, still he somehow did not considered extra support 
measures than were described in the contract documents (HPL, 1996c), which was one of the major weakness of this Turnkey contract. After tunnelling of about $2.5 \mathrm{~km}$ headrace tunnel from different construction Adits the Contractor realized that he did a huge mistake for not being carefully evaluated geological conditions along the headrace tunnel before signing the KC2 Contract. He became convinced that the estimated rock mass quality presented during contract negotiation was not correct and discrepancies from the prediction would be considerable. Actually mapped rock mass quality condition along the headrace tunnel is presented in Figure 5 where it can be seen that the level of discrepancies between predicted and actual rock mass quality is huge.

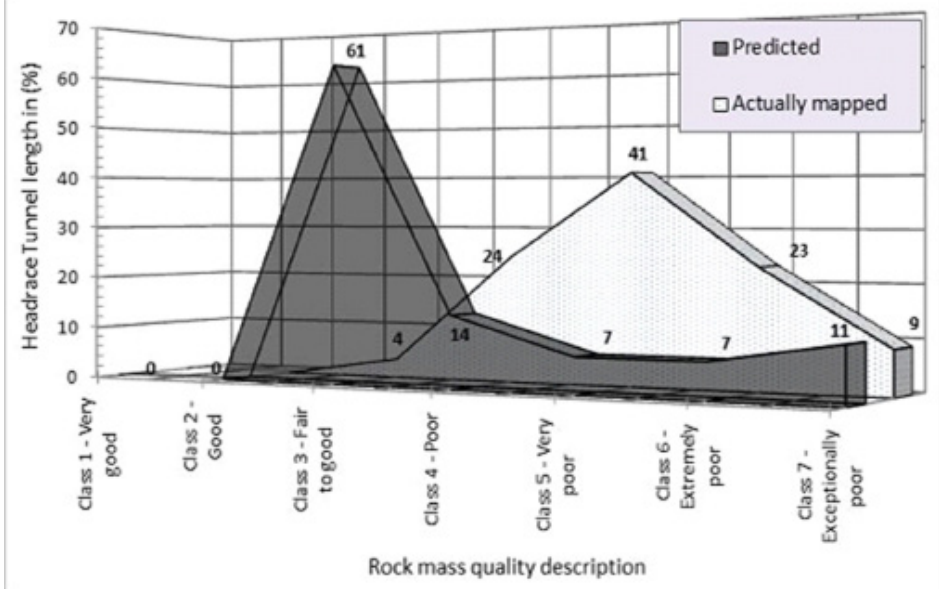

Figure 5: Predicted and actually mapped rock mass quality condition along the headrace tunnel.

Figure 5 clearly shows, only four percentage of the tunnel length had Rock Mass Quality Class 3 - Fair to Good instead of the predicted 61 percent length. Note that the dominating rock quality class that was observed during tunnel excavation felled to Rock Mass Quality Class 5 - Very Poor with 41 percent in contrast to the predicted one of only 7 percent. The level of quality deviation was out of imagination to the Contractor. The Contractor was forced to mechanise tunnelling work and use extra support measures to accelerate the work. In addition, due to high degree of fracture intensity (jointing) in the rock mass, the Contractor also needed to take additional measure of systematic injection grouting along the headrace tunnel (Panthi, 2013) to limit potential water leakage through the headrace tunnel so that he could avoid costly and time consuming full concrete lining of the headrace tunnel.

\section{Geological Conditions along Upper Pressure Shaft}

Another geological risk that the Contractor had to confront was excavation of $438 \mathrm{~m}$ long inclined Upper Pressure Shaft (UPS). UPS alignment follows two category rocks; i.e. the rock above shear zone (Figure 4) representing mica gneiss and micaschist intercalation where the rock mass was weaker consisting series of bands of highly sheared micaschist in short intervals and below from this shear zone more relatively competent but fractured augen gneiss. More importantly, as seen in Figure 4, the upper part of UPS follows relatively low rock cover (less than $100 \mathrm{~m}$ ). In the original design proposed by the Client, the 45 degrees inclined UPS was aligned further towards the surface topography with only 50 meter horizontal pressure tunnel segment upstream from the junction of Adit 5 (Figure 4). The Contractor followed this alignment and begun to carry out shaft excavation. However, after excavating $186 \mathrm{~m}$ shaft, a catastrophic collapse occurred. The Contractor made several days effort to clear out slide mass, however rock mass did not stop sliding down even after mucking many hundred cubic meters of rock mass. It was realized that the collapse would reach all the way to the surface if not stopped for further clearing. It was also understood that following this alignment further would increase uncertainty in the completion of this shaft. Hence, this original alignment was abandoned and the new alignment was pushed further into the rock mass by increasing horizontal tunnel $50 \mathrm{~m}$ further (Figure 4). The collapse and additional excavation with changed alignment was certainly a serious setback with respect to both financial and time consequences.

To compensate the time, Contractor had decided to excavate Upper Pressure Shaft from two fronts; i.e. from Adit 5 up by using originally planned Alimak Raise Climber and from Adit 4 down by sinking the shaft. Shaft excavation from Adit 5 went smoothly along this new alignment until a collapse occurred at $352 \mathrm{~m}$ chainage in July 1998. By this time, 68 $\mathrm{m}$ shaft sinking was already done from Adit 4. Since only $18 \mathrm{~m}$ shaft excavation was remaining, no effort was made to further excavate the shaft from Adit 5 up. Finally, a breakthrough took place at the end of November 1998. After excavation completion, the crew begun to erect rail line so that UPS becomes ready for penstock pipe installation and concrete embedding. However, after $295 \mathrm{~m}$ rail erection from Adit 4, a new collapse at already excavation completed UPS was occurred at chainage $138 \mathrm{~m}$ from the bottom.

The consequence of this new collapse was severe and the Milestone No. 10 - UPS ready for penstock installation, which was scheduled to be achieved by 24th September 1998 (Table 2) was no more possible to achieve. Clearing and stabilization operation continued. However, a new collapse occurred once again at chainage $132 \mathrm{~m}$ from the bottom, which further impacted on the MS 10 achievement. Finally, on 14th August 1999, after 324 days delay from the Milestone No. 10 target, the Upper Pressure Shaft became ready for penstock erection. This delay was huge that would give direct impact on other three major Milestones to be achieved; i.e. MA 12 scheduled for 8th November 1999, MS 13 scheduled for 11th March 2000 and MS 14 scheduled for 11th July 2000 (Table 2).

\section{Penstock Erection Work at UPS}

The Contractors (both Civil and Electro-mechanical) had gained substantial experience from Penstock Installation and Concrete Embedding work at the $471 \mathrm{~m}$ long Lower Pressure Shaft (LPS), which took almost 235 days to complete. This achievement was alarming for 
installation and concrete embedding work at the UPS. If the Contractors follow similar strategies, there was no way that the project could achieve MS 14 - Commercial Operation scheduled for 11th July 2000. Not being able to achieve this target would lead to liquidated damage payment to HPL (the Client) amounting US\$27,000 per day. Since Civil and Electro-mechanical work activities at Powerhouse were within schedule and work at Headworks were almost completed, only causes for delay was associated to the completion of penstock pipe installation and concrete embedding work at UPC and subsequent concrete lining work between Adit 4 junction and the bell-mouth of the penstock. Therefore, well-coordinated team work was the must, which in fact was achieved. The penstock installation and concrete embedding work at UPS was completed on 24th November in only 102 days, which should have been the world record. In the higher management level of both Contractors, nobody thought it was possible to achieve. With this achievement, the new light emerged with the hope to achieve what Contractor promised to achieve while signing the $\mathrm{KC} 2$ contract.

\section{Geological Risk at LPS, Access and Tailrace Tunnels}

The rock type along these tunnels was mainly massive and jointed augun gneiss. The rock mass quality conditions were not as similar as that was indicated in the contract documents. The cost of construction and rock support work were increased in these areas too with respect to the estimated ones. However, no serious scale collapse occurred excluding some small to medium scale block falls and overbreaks, which were not difficult to tackle.

\section{Claim for Extension of Construction Time}

As mentioned earlier, there were not many possibilities to make claims on the financial cost recovery caused by the geological variation under KC2 Contract. However, efforts were made to claim the extension of construction time deemed due to four collapses that occurred at the Upper Pressure Shaft. In addition, time extension claims were also related to the difficulties in the supply chain caused by delayed customs clearance on the imported equipment and construction material and also time claim caused by the potential risk of Glacier Lake Outburst Floods (GOLFs). Altogether the Contractor claimed for almost 400 days of time extension. After series of negotiation with the Client, an extension of 93 days was achieved. This achievement led to push Milestone No 13 - Substantial Completion of the project to 12th June 2000. This change still gave the Client to achieve MS 14 - Commercial Operation of the plant scheduled for 11th July 2000, which was a contractual binding day of the Client with the Government of Nepal.

\section{Achievement of Substantial Completion}

With the completion of penstock installation and concrete embedding work at the Upper Pressure Shaft, all effort were placed to complete the $148 \mathrm{~m}$ length concrete lining segment of headrace tunnel downstream from Adit 4 junction to the Penstock cone and the concrete lining work at the junction and bulkhead door area of Adit 4. All concrete lining works were completed at this area by the end of February 2000. With new Substantial Completion Milestone of 12th June both $\mathrm{KC} 2$ Contractor and ESIS Contractor convinced that this milestone will be achieved and also started to accelerate work so that some days of early completion bonus is achieved. Finally, the $\mathrm{KC}_{2}$ Contractor (Civil Construction Consortium) declared Substantial Completion on 2nd May 200o. After series of meetings, HPL (the Client) and its sponsors accepted 39 days of early completion of all works and the Civil contractor was awarded with the entitled early completion bonus of US\$ 468,000 (39 days x 12,000 US\$). Similarly the Electro-mechanical Contractor was paid with US\$ 312,000 as an early completion bonus.

\section{Conclusions}

Managing construction activities at Khimti I Hydropower Project were extremely difficult. The geological risks that existed at this project were huge and the Contractor faced considerable amount of financial loss caused by the changes in the geological conditions, especially along the headrace tunnel and inclined upper pressure shaft. The best part of this project was that the KC2 Contractor never gave up hope in achieving the commercial operation milestone set for 12th July 2000. The work at Khimti I Hydropower Project demonstrated that with an experienced leadership (management), team work and dedication of the workforce it is possible to complete projects within given timeframe even in the Himalayan rock mass conditions. The experience and lesson learned from managing this challenging project under Turnkey contract were substantial for both Civil and Electro-mechanical Contractors. The most important lesson was that the Contractor must be careful in accepting and signing the Turnkey Contract and it needs verifications and quality check of the pre-construction phase engineering geological investigations and data input provided by the Client and also verification on the real ground condition at site. In addition, some short of geological risk sharing mechanism must be included in the Turnkey contract.

\section{Acknowledgement}

The author himself served as the Construction Manager of Khimti I Hydropower Project from the middle of 1998 until the completion of defect liability period (January 2002). The views expressed and analyses presented are based on the actual happenings and experience of the author. The author feels proud working with the whole project team under $\mathrm{KC} 2$ contract.

Dr. Krishna Kanta Panthi, holds PhD in Rock Engineering and MSc in Hydropower Engineering. He works as Associate Professor of Geological engineering at the Department of Geology and Mineral Resources Engineering, Norwegian University of Science and Technology (NTNU), Norway. He has over 22 years of experience in tunnelling, hydropower planning and design, construction management, and mining technologies. 


\section{References}

Civil Construction Consortium/CCC. 2002. Civil Construction Report, Khimti I Hydropower Project, Volume 1 - Main Text, May 2002.

Himal Power Limited (HPL). 1996a. Civil Construction and Engineering Contracts KC2", Khimti I Project Civil Works Contract, Design Basis Memorandum, January 1996.

Himal Power Limited (HPL). 1996b. Civil Construction and Engineering Contracts KC2, Khimti I Project Civil Works Contract, Main Volume, January 1996.

Himal Power Limited (HPL). 1996c. Civil Construction and Engineering Contracts KC2, Khimti I Project Civil Works Contract, Annex D, J, K \& O, January 1996.

Ministry of Water Resources (MoWR). 1993. Feasibility Study Report by Butwal Power Company, Nepal and
Norpower AS Norway, Khimti I Hydropower Project, Volume 1 - Main Text, January 1993.

Panthi K. K. 2006. Analysis of Engineering Geological Uncertainties related to Tunnelling in Himalayan Rock Mass", Norwegian University of Science and Technology, Doctoral Thesis 2006:41, ISBN 82-4717826-5.

Panthi K. K. and Nilsen B. 2007. Predicted versus actual rock mass conditions: a review of four tunnel projects in Nepal Himalaya. Tunnelling and underground space technology, vol. 22, no 2, pp. 173-184.

Panthi, K. K. 2011. Effectiveness of post-injection grouting in controlling leakage: A case study, Hydro Nepal, Journal of Water, Energy and Environment, Issue No. 8, January 2011.

Panthi K. K. 2013. Pre-injection versus post-injection grouting - a review of a case from the Himalaya, Proceedings: ARMA 2013 held in San Francisco from 23rd to 27th June, 2013. 